\title{
Obrączka ślubna - jej historia i znaczenie w tradycji Kościoła prawosławnego
}

\author{
ks. Adam Magruk \\ Chrześcijańska Akademia Teologiczna \\ Polska \\ admagruk@wp.pl
}

Fr. Adam Magruk, The Wedding Ring - Its History and Significance in the Tradition of the Orthodox Church, Elpis, 18 2016: 81-86.

\begin{abstract}
In Orthodox Church practice, the Sacrament of Marriage is always preceded by the Rite of Engagement (gr. $\alpha \rho \rho \alpha \beta \dot{\omega} v$ ), which is a prelude to the main ceremony. It is a sort of assurance that is given by a fiancée and a bridegroom which means that they intend to embark on a path of married life, and the engagement period allows them to prepare for that. This is also borne out by the translation of the ancient Greek term $\alpha \rho \rho \alpha \beta \omega v$ (Hebrew: ērābōn), which means i.e. a guarantee, surety and pledge. However, Fr. J. Meyendorff interpolates that an engagement (...) is something more than just an obligation or duty. It expresses the actual marriage bond, which lacks only the sublime sacramental object. That is why it is celebrated just before wedding service. Its central moment is the placing on the fingers of the bride and groom wedding rings with the accompanying words of the priest: The servant of God (name) is betrothed to the handmaiden of God (name) in the name of the Father, and of the Son, and of the Holy Spirit. Amen, and The handmaiden of God (name) is betrothed to the servant of God (name), in the name of the Father, and of the Son, and of the Holy Spirit. Amen.

Wedding ring is a sign, proof and pledge of the marriage of the bride and groom. Its circular form has neither beginning nor end, which is a symbol of eternity. The matter of which it is made has to constantly remind the spouses of the fact that they themselves did not put it on their fingers, but the One who is Alpha and the Omega, the First and the Last, the Beginning and the End, and that the love which has joined them together will be often put to the test. However, just as gold is tried in the fire and is not damaged in any way, so their love, in difficult times, will resist arrows of temptations of the enemy of the human race directed at them.
\end{abstract}

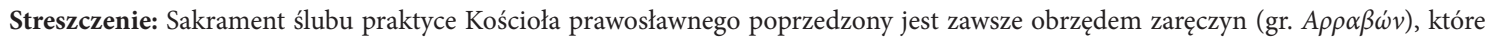
stanowi niejako jego preludium. Jest ono swego rodzaju, zapewnieniem ze strony narzeczonych, iż zamierzają oni wstąpić na drogę życia małżeńskiego, do którego pozwala przygotować się okres narzeczeństwa. Potwierdza to także samo tłumaczenie starogreckiego terminu $\alpha \rho \rho \alpha \beta \omega \dot{v}$ (z hebr. ērābōn), oznaczające m.in. gwarancję, porękę, zastaw. Ks. J. Meyendorff dodaje jednak, iż zaręczyny (...) są czymś więcej niż zwykłym zobowiązaniem czy obowiązkiem. Wyrażają one rzeczywistą więź małżeńską, której brakuje jedynie podniosłego sakramentalnego dopełnienia. Dlatego właśnie celebruje się je tuż przed nabożeństwem ślubu. Jego centralnym momentem jest założenie na palce narzeczonych obrączek wraz z towarzyszącym temu słowach kapłana: Zaręczany jest sługa Boży (imię) ze służebnicą Bożą (imię), w imię Ojca i Syna, i Świętego Ducha. Amen, oraz: Zaręczana jest służebnica Boża (imię) ze sługą Bożym (imię), w imię Ojca i Syna, i Świętego Ducha. Amen.

Obrączka ślubna jest oznaką, dowodem i rękojmią zaślubin dwojga narzeczonych. Jej kolista forma, nieposiadająca ani początku, ani końca, która jest symbolem wieczności. Materia, z której się ją wykonuje ma stale przypominać małżonkom o tym, iż to nie oni sami, ale Ten, Który jest Alfą i Omegą, Pierwszym i Ostatnim, Początkiem i Końcem włożył ją na ich ręce a miłość, jaka ich połączyła będzie niejednokrotnie wystawiana na próbę, lecz tak jak prawdziwe złoto doświadczane w ogniu nie ulegnie jakiemukolwiek uszkodzeniu, tak i ich miłość w chwilach trudnych odpierać będzie strzały pokus jakie kierować w nich będzie wróg rodzaju ludzkiego.

Keywords: wedding ring, rite of engagement, sacrament of marriage, Orthodoxy

Słowa kluczowe: obrączka, obrzęd zaręczyn, sakrament ślubu, prawosławie

\section{Wstęp}

Sakrament Ślubu praktyce Kościoła Prawosławnego

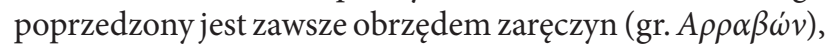
które stanowi niejako jego preludium. Jest ono swego rodzaju zapewnieniem ze strony narzeczonych, iż zamierzają oni wstapić na drogę życia małżeńskiego, do którego pozwala przygotować się okres narzeczeństwa ${ }^{1}$. Potwierdza to także

\footnotetext{
Początkowo, jako uznawane za akt czysto świecki, sprawowane było ono oddzielnie od właściwego nabożeństwa Ślubu. Odbywało się zazwyczaj w domu narzeczonych, w obecności najbliższej rodziny. Towarzyszyło mu uroczyste podpisanie przysięgi oficjalnego zawarcia w nieokreślonej czasowo przyszłości małżeństwa i wymiana darami ( $w$ tradycji starotestamentowych Izraelitów jak również i w prawie asyryjskim i babilońskim mowa jest o zapłacie jedynie ze strony narzeczonego, pewnej sumy pieniędzy
}

samo tłumaczenie starogreckiego terminu $\alpha \rho \rho \alpha \beta \omega ́ v$ (hebr. èräbōn), oznaczające m.in. „gwarancję”, „porękę", „zastaw”.

ojcu przyszłej panny młodej, która była swego rodzaju wykupem kobiety od jej rodziny). Ze względu jednak na to, że chrześcijanie mieli w zwyczaju rozpoczynać każde ważne wydarzenie w swoim życiu od modlitwy -prośby do Boga o Jego błogosławieństwo, Kościół udziela takiej właśnie możliwości w postaci rytu zaręczyn, który dziś w większości przypadków ma miejsce w dniu ślubu i odbywa się w przedsionku świątyni, co jest nawiązaniem do dawnej praktyki jego sprawowania poza murami Kościoła. Г.И. Шиманский, Литургика: Таинства и обряды, wyd. Сретенский

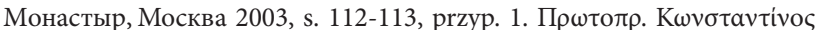

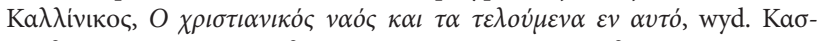

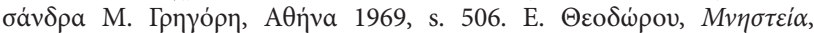

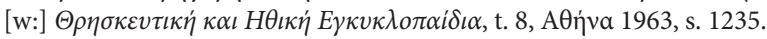

2 Co ciekawe, nowogrecki termin $\varepsilon \gamma \gamma u ́ \eta \sigma \eta$ - „gwarancja”, w starej grece

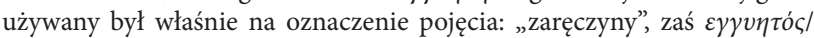

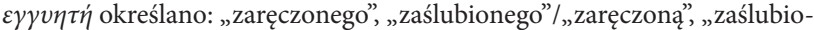


Ks. J. Meyendorff dodaje jednak, iż zaręczyny (...) sa czymś więcej niż zwyklym zobowiązaniem czy obowiazkiem. Wyrażaja one rzeczywista więź małżeńską, której brakuje jedynie podniostego sakramentalnego dopetnienia. Dlatego właśnie celebruje się je tuż przed Nabożeństwem Ślubu. Jego centralnym momentem jest założenie na palce narzeczonych obrączek wraz z towarzyszącymi tej chwili słowami kapłana: Zaręczany jest sługa Boży (imię) ze stużebnica Boża (imię), w imię Ojca i Syna, i Świętego Ducha. Amen, oraz: Zaręczana jest stużebnica Boża (imię) ze sługa Bożym (imię), w imię Ojca i Syna, i Świętego Ducha. Amen ${ }^{4}$.

Obrączka jest bodajże najbardziej charakterystycznym i rozpoznawalnym dziś symbolem poślubionego człowieka. Warto byłoby zastanowić się w tym miejscu nad jej historią i rolą jej przypisywaną.

\section{1. Świadectwa biblijne i czasy starożytne}

Pismo Święte nie szczędzi informacji na temat różnorodności funkcji jakie spełniał pierścień. Spotykany jest on przede wszystkim jako część ozdoby-biżuterii. Judyta na ten przykład, by przyciągnąć wzrok mężczyzn - a zwłaszcza Holofernesa - oprócz łańcuszków, bransolet, kolczyków i innych ozdób nakłada również pierścienie ${ }^{5}$. O jego dekoracyjnej roli wspomina także prorok Izajasz w swej mowie skierowanej przeciwko wyniosłym mieszkankom Jerozolimy ${ }^{6}$. W innych miejscach Biblii przybiera ono inne znaczenie. Jest symbolem władzy, godności, zaszczytu, czci i szacunku. W Księdze Rodzaju pierścień z pieczęcią, obok laski i sznura stanowi insygnia przywódcy szczepu ${ }^{7}$. Z kolei Faraon, mianując Józefa zarządcą całego Egiptu, zdejmuje swój pierścień z palca i wkłada go na palec pierworodnego Racheli ${ }^{8}$, zaś król Dariusz pieczętuje nim wejście do jaskini lwów, do której na jego rozkaz wrzucono proroka Daniela9 a Aswersus wręczając sygnet Hamanowi, daje mu $\mathrm{w}$ ten sposób wolną rękę w kwestii traktowania Żydów ${ }^{10}$. $\mathrm{W}$ przypowieści o synu marnotrawnym natomiast, staje się on symbolem przywrócenia synowskiej godności ${ }^{11}$. Według informacji zawartych w Liście apostoła Jakuba, złoty pierścień jest jednym ze znaków rozpoznawczych człowieka bogatego ${ }^{12}$. Do tych i innych miejsc Słowa Bożego,

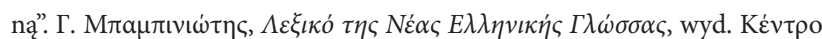

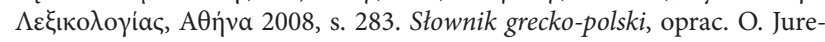
wicz, t. 1, wyd. PWN, Warszawa 2000, s. 111, 248.

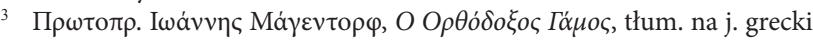

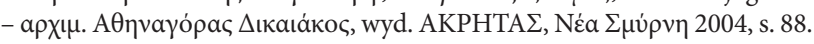

4 Obrzęd zaręczyn, modlitwa na założenie narzeczonym obrączek. Tekst w j. polskim zacytowano na podstawie: http://liturgia.cerkiew.pl/euch/ malzenstwo/zareczyny.pdf [dostęp 17.06.2013].

5 (Jdt 10, 4). Cytaty Pisma Świętego podano za: Biblia Tysiąclecia. Pismo

święte Starego i Nowego Testamentu, wyd. Pallotinum, Poznań 2000.

6 (Iz 3, 18-21).

(Rdz 38, 18).

(Rdz 41, 42).

9 (Dn 6, 17-18).

10 (Est 3, 10-12). Patrz także: (Est 8, 2.8.10).

11 (Łk 15, 22).

$12(\mathrm{Jk} 2,2)$. które odnoszą się do zastosowania pierścienia nawiązuje także modlitwa obrzędu zaręczyn, rozpoczynająca się od słów: Panie Boże nasz, który studze patriarchy (...). Czytamy w niej m.in.: Ty bowiem, Panie, nakazateś dać pierścień i pierścieniem umacniać wszystkie umowy. Poprzez pierścień dana zostata Józefowi władza w Egipcie, poprzez pierścień uczczony został Daniel w kraju babilońskim, poprzez pierścień objawita się prawda Tamary, poprzez pierścień Ojciec nasz niebieski okazat szczodrobliwość swemu synowi. Powiedział bowiem: „Włóżcie pierścień na jego prawicę, zabijcie cielca tuczonego i jedzac radujcie się"13.

W starożytności pierścień był ponadto widzialnym symbolem zawieranego między dwiema stronami porozumienia ${ }^{14}$. Przełamany na dwie połówki był znakiem rozpoznawczym osób, których łączyły więzi przyjaźni, partnerskie czy formalne. W życiu codziennym służył on też za pieczęć, która pełniła rolę poświadczającą o tożsamości nadawcy - w przypadku listu, przesyłki, bądź też właściciela-sprzedawcy - w wymianie handlowej ${ }^{15}$. W przekonaniu plemion zamieszkujących Bliski Wschód czarodziejskie pierścienie chroniły ich przed chorobami i czyhającymi na nich nieszczęściami. W antycznej Grecji ich noszenie było przywilejem jedynie ludzi wolnych. Bardzo ceniono sobie tam pierścień z wyrytym herbem lub literami, którego używano zamiast pieczęci ${ }^{16}$. Tymczasem, niejednemu azjatyckiemu ludowi, pierścień kojarzył się głównie z niewolnictwem i jak zauważa Reinaud wyrażenia takie jak na przykład.: „mieć pierścień w uchu” lub „mieć przekłute ucho”, oznaczało po prostu - „być niewolnikiem” ${ }^{17}$. W Rzymie z kolei, godność noszenia złotych pierścieni mieli senatorowie, kapłani Jowisza, rycerze oraz trybunowie wojskowi. Przedstawiciele niższych warstw społecznych jak na przykład plebejusze czy pozbawieni wolności, nosili pierścienie wykonane z metalu, co miało na celu ich odróżnienie od utrzymujących się przy władzy ${ }^{18}$. Prawdopodobnie to właśnie w Rzymie po raz pierwszy pojawił się zwyczaj wzajemnej wymiany obrączkami przez zawierających związek małżeński ${ }^{19}$, które podobnie jak u starożytnych Etrusków były bardzo proste i wykonywane z żelaza ${ }^{20}$.

Od około III w. n.e., tradycja Judaizmu rabinistycznego wzbogacona zostaje o nowe, nieznane dotąd elementy w obrzędzie błogosławieństwa młodej pary. Oprócz odmówienia specjalnych modlitw oraz błogosławieństwa kieli-

\footnotetext{
Obrzęd zaręczyn, Modlitwa wypowiadana tuż po założeniu narzeczonym obraczek. Tekst w j. polskim zacytowano na podstawie: http:// liturgia.cerkiew.pl/euch/malzenstwo/zareczyny.pdf [dostęp 17.06.2013].

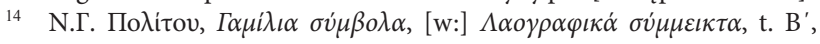
Aөíva 1921, s. 224.

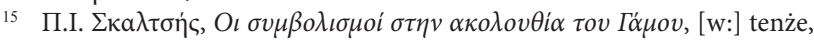

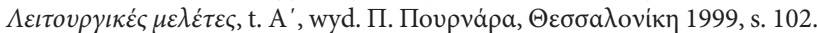

16 D. Forster, Świat symboliki chrześcijańskiej. Leksykon, tłum. zbiorowe, wyd. PAX, Warszawa 2001, s. 423.

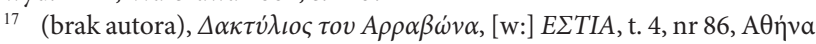
1877, s. 541-542.

$18 \mathrm{~W}$ tradycji licznych ludów azjatyckich, kobiety do dnia dzisiejszego na dowód bezwzględnego podporządkowania się woli mężczyzny zakładają

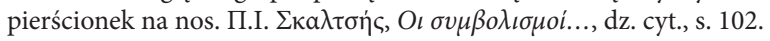

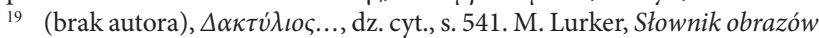
i symboli biblijnych, wyd. Pallottinum, Poznań 1989, s. 175.

20 D. Forster, Świat symboliki..., dz. cyt., s. 423.
} 
cha $\mathrm{z}$ winem wspomina się również i o tym, że narzeczony nakłada na palec niewiasty pierścień - obowiązkowo bez kamienia lub innych dodatkowych ozdób - wypowiadając przy tym następujące słowa: Oto ty jesteś mi poświęcona tym oto pierścieniem, zgodnie z Prawem Mojżesza i Izraela ${ }^{21}$.

\section{Pisma Ojców i nauczycieli Kościoła}

Pierwsze wzmianki o zastosowaniu pierścienia na gruncie chrześcijańskim znajdziemy u żyjącego w drugim stuleciu Tertuliana, który informuje, że w jego czasach, tradycja jego noszenia była powszechnie znana wśród pogan, lecz nie miało to żadnego związku z ich życiem religijnym $^{22}$. Łaciński pisarz dodatkowo zaświadcza, iż chrześcijanie niezwykle szybko zaadoptowali od nich tradycję wręczania sobie obrączek przez pobierające się osoby, co miało na celu potwierdzenie przysięgi jaką składali oni sobie wówczas nawzajem ${ }^{23}$. Św. Klemens Aleksandryjski (II w.) w jednym z najbardziej swoich znanych dzieł pt „Pedagog”, zwraca uwagę na to, że pierścień-pieczęć noszony przez chrześcijan powinien mieć wyryty symbol gołębia badź ryby lub statek płynacy ze sprzyjajacym wiatrem, lub harfe, której używał Polikrates, bądź kotwicę, którą naniósł Seleukos na własny sygnet $(\ldots)^{24}$. Wzmiankuje on tam również o tym, że mężczyzna „zaopatruje” kobietę w tego rodzaju złoty pierścionek, którym oznaczał przedmioty mające związek z ochroną, zabezpieczeniem domostwa przed niebezpieczeństwami ${ }^{25}$, podkreślając w ten sposób ważną rolę kobiety, jako reprezentanta głowy rodziny podczas jego nieobecności ${ }^{26}$. N.G. Politou uważa, że także w tradycji mieszkańców „Wiecznego Miasta”, jedynie narzeczony wręczał swej wybrance obrączkę. Przez wiele stuleci tradycji tej trzymał się również i Kościół, czego potwierdzeniem może być list papieża Mikołaja I - za pontyfikatu którego obrączka staje się już obowiązkowym elementem nabożeństwa ślubnego - do Bułgarów z 866 roku, ale i datowane jeszcze na wiek XIII niemieckie poematy wzmiankują o niej w swej treści ${ }^{27}$. W średniowiecznych opowiadaniach jednak, niejednokrotnie mowa jest i dawaniu pierścienia tylko ze strony kobiety. Wystarczy choćby przywołać na pamięć siedemnastowieczną grecką powieść pt. „Erotokrios”, w której to Aretusa, przekazując tytułowemu bohaterowi pierścionek,

\footnotetext{
21 M.S. Żełtow zauważa jednak, że w Talmudzie mowa jest nie o pierścieniu a monecie, zaś u jemeńskich Żydów do dnia dzisiejszego pan młody w chwili zaręczyn mówi do swej narzeczonej: Oto ty jesteś mi poświęcona $w$ ta moneta. М.С. Желтов, Брак, [w:] Православная Енциклопедия, t. 6, wyd. Церковно-научный центр Православная Енциклопедия, Москва 2003, s. 167

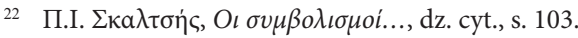

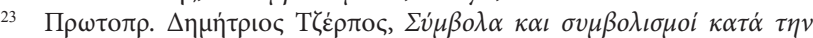

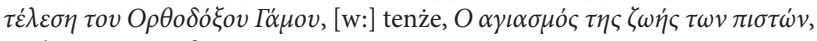

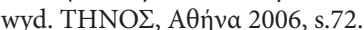

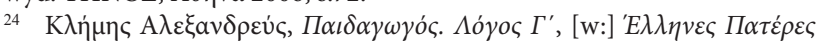

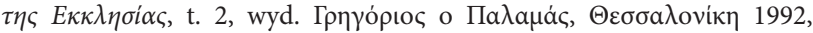
s. $335-337$

25 Tamże, s. 335.

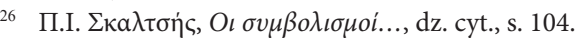

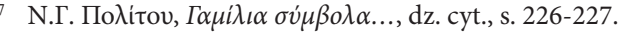

prosi go by ten nosił go zawsze na swym ręku w znak tego, że jest jej dozgonnym towarzyszem życia ${ }^{28}$.

Błędem byłoby pominięcie w tym miejscu pouczenia wielkiego kaznodziei św. Jana Chryzostoma (IV w.), u którego pierścieniem określany jest Święty Duch, Jego łaska, którą posłał Chrystus swym apostołom mówiąc: przyjmijcie $i$ dajcie go (pierścień) wszystkim ${ }^{29}$. To właśnie za jego pośrednictwem Zbawiciel zaręczył się z Kościołem ${ }^{30}$. I choć Złotousty w tym miejscu nie mówi dosłownie o zwyczajach ślubnych panujących w jego epoce, to wyraźnie daje do zrozumienia, że „zastosowanie” zaręczynowej obrączki było już wówczas powszechnie znane.

Jako ciekawostkę należałoby dodać, że wyraźne rozróżnienie między nazywanym obecnie pierścionkiem zaręczynowym a samą obrączką pojawia się dopiero około wieku XIV, kiedy to biskup Rzymu Innocenty VI podkreśla już dosadnie konieczność oficjalnego ustanowienia obowiązkowego okresu poprzedzającego ślub, czyli - narzeczeństwa, co „zaowocuje” użyciem pierścionka zaręczynowego przy oświadczynach. Po raz pierwszy wspomina się o nim w biografii archiduxa Maksymiliana Habsburskiego, który w 1477 r. prosząc o rękę swej wybranki, wręcza jej pierścień $\mathrm{z}$ diamentowym kamieniem. To prawdopodobnie właśnie jego „czyn” stał się inspiracją do powstania nowej tradycji zaręczynowej ${ }^{31}$.

Źródła patrystyczne, a wraz z nimi inni znani teolodzy, dostarczają również, interesujących informacji związanych $\mathrm{z}$ materią, z której wykonane powinny być ślubne obrączki ale i wyjaśnienia w kwestii „miejsca” na dłoni, w którym jest noszona.

P. Trempelas w swoim „Małym Euchologionie”, na który zsyła się również E. Theodorou ${ }^{32}$, zaznacza, że zgodnie z przekazem historycznych kodeksów liturgicznych, potrójna wymiana obraczkami podczas obrzędu zaręczyn odbywa się $w$ taki sposób, aby złota trafiła na koniec do mężczyzny, natomiast srebrna, lub żelazna bądź miedziowa do kobiety $^{33}$. Potwierdzają to chociażby kodeksy Narodowej Biblioteki Ateńskiej z XII i XV w., czy też te pochodzące $\mathrm{z}$ atoskich wspólnot monastycznych: Wielkiej Ławry i Koutloumousiou ${ }^{34}$. Św. Symeon Tessalonicki (XV w.), jakby na przekór powyższemu zaznacza, iż mężczyźnie powinna być przeznaczona obrączka z żelaza - symbolizującego siłę i moc płci męskiej, natomiast kobiecie ze złota - znaku czystości i delikatności ${ }^{35}$. Bazując na przekazach innych jeszcze rękopisów z piętnastego stulecia i młodszych, zauważa się, iż narzeczony nosi srebrny, zaś jego wybranka

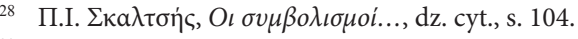

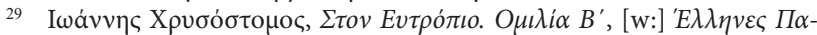
$\tau \dot{\varepsilon} \rho \varepsilon \varsigma . . .$, dz. cyt., t. 33, s. 147-149.

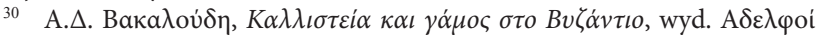

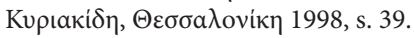

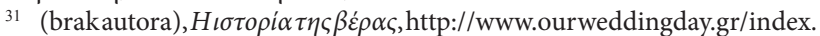
$\mathrm{php/mnuweddinguide/wedding/jewelrynaccessories/42-2011-05-02-16}$ -49-32 [dostęp 20.09.2014].

32 E. $\Theta \varepsilon o \delta \omega ́ \rho \rho o v, ~ M v \eta \sigma \tau \varepsilon i \alpha \ldots$, dz. cyt., s. 1238.

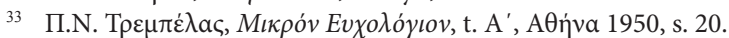

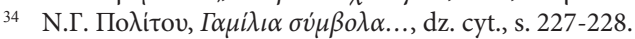

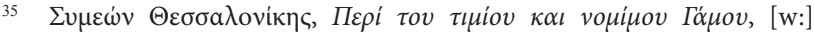
J.- P. Migne, Patrologiae Cursus Completus, Series Graeca, t. 155, Paris 1857-1866, s. 508A.
} 
złoty pierścień. Jeden z najbardziej znanych i czczonych nauczycieli i oświecicieli narodu greckiego - św. Kosmas Aitolos (XVIII w.) tłumaczył to w ten oto zwięzły, ale dobitny sposób: kobieta powinna być czysta niczym złoto, a mężczyzna silny jak srebro ${ }^{36}$. Co ciekawe jednak, do dnia dzisiejszego w „Euchologionie” zachowała się wskazówka - mająca związek z przeciwną do tej ostatniej - o następującej treści: Kapłan bierze obrączki i podaje najpierw złota mężczyźnie, a potem srebrna kobiecie ${ }^{37}$. Ta z kolei, ma inne, bardziej metaforyczne przesłanie. Mężczyzna przedstawia tu sobą słońce zaś narzeczona zajmuje miejsce księżyca, które otrzymuje światło od tego pierwszego ${ }^{38}$. Obecnie obrączki obojga narzeczonych w większości przypadków są złote. Kościół pragnie za pomocą takiego zabiegu, jeszcze wyraźniej uwypuklić zachodzącą pomiędzy nimi równość i wzajemne uzupełnianie.

Bardzo interesującym może być również tekst jednego z piętnastowiecznych kodeksów atoskiego Monasteru Pantokratora, który mówi o tym, że kapłan oprócz dwóch obrączek wręcza każdemu z narzeczonych po jednym bochenku chleba. Ci natomiast wymieniają je nawzajem wraz z pierścieniami co miało symbolizować, iż od tej pory wszelkie rzeczy materialne są już wspólne ${ }^{39}$.

Z twórczości wielu znanych filozofów, pisarzy i historyków starożytności takich jak np.: Plutarch (I-II w.), Gelliusz (II w.), czy Lukian (II w.), czerpiemy wiadomości, z których wynika, że już wówczas przydawano symbolicznej mistycznej roli noszenia pierścienia na palcu serdecznym lewej ręki. Grecy i Rzymianie powszechnie zaakceptowali powyższą tradycję, opierając się głównie na opinii Egipcjan zajmujących się balsamowaniem ciał zmarłych, zgodnie z obserwacjami których, delikatny nerw lub żyła mające swój początek w tymże palcu dociera aż do samego serca ${ }^{40}$ - źródła życia i miłości. Pogląd ten potwierdzi także w swych „Etymologiach”, żyjący ok. pięciu wieków później św. Izydor z Sewilli ${ }^{41}$. Kontynuatorem owego egipskiego zwyczaju są dziś m.in.: Amerykanie, Brazylijczycy Irlandczycy czy Grecy, noszący obrączkę na lewej ręce w przeciwieństwie do większości krajów Europy w tym także w Polski, mieszkańcy których zakładają ją na prawą rękę właśnie stąd czerpie swe źródło dawna polska tradycja grawerowania na obrączkach ślubnych wiersza: Serce moje i twoje, połacz Boże oboje ${ }^{43}$.

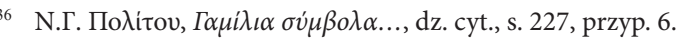

37 Obrzęd zaręczyn, podpowiedź skierowana w kierunku sprawującego nabożeństwo kapłana, umieszczona tuż po odmówionej modlitwie: „Panie Boże nasz, który spośród narodów (...)”. Tekst w j. polskim zacytowano na podstawie: http://liturgia.cerkiew.pl/euch/malzenstwo/zareczyny.pdf [dostęp 17.06.2013].

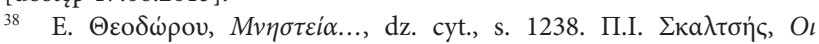

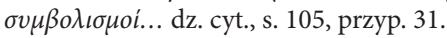

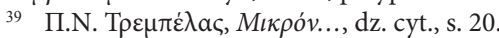

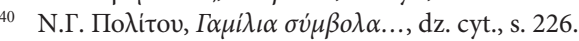

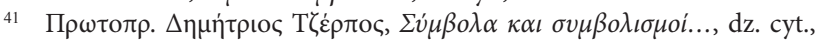
s. 72, przyp. 19.

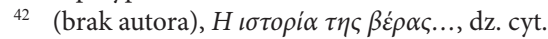

43 Na terenie Polski obrączka cieszyła się od wielu stuleci ogromnym szacunkiem najdroższej pamiątki, składanej niekiedy jako wotum dziękczynne za otrzymane łaski przy ikonach, relikwiach świętych. Z czasem zaczęto nawet grawerować na jej wewnętrznej stronie imiona i nazwiska właści-
}

Na szczególną uwagę zasługuje także umiejscowienie obrączek jeszcze przed ich nałożeniem na ręce narzeczonych. Według wybitnego greckiego liturgisty I. Phountoulisa, przed rozpoczęciem obrzędu Zaręczyn, obrączki ślubne pierwotnie umieszczano na Ołtarzu (gr. Ayí

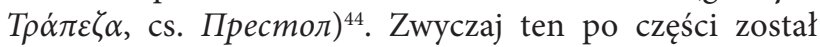
przejęty przez tradycję słowiańską. Niekiedy kapłan kładzie obraczki na Oltarzu, jeszcze zanim wyjdzie sprawować nabożeństwo (Ślubu) na środek świątyni; a innym razem wyszedtszy już na nabożeństwo, bierze obraczki i odnosi je do ottarza, i po powrocie stamtąd rozpoczyna nabożeń$s t w o^{45}$ - pisze ks. S. Bułhakow. Abp Beniamin (Rumowskij) dodatkowo, nie pozostawia złudzeń co do faktu, że odmawianie oddzielnej modlitwy nad ślubnymi obrączkami oraz ich święcenie jest nieprawidłowe ${ }^{46}$ a tylko co cytowany rosyjski duchowny, idąc za ks. T. Sieredinskim kropienie ich święconą wodą określa zwyczajem nieprawosławnym i łacińskim ${ }^{47}$ - ponieważ samo tylko ich dotknięcie do św. Stołu już je uświęca ${ }^{48}$.

Nieco inaczej rzecz ma się w praktyce Kościoła Greckiego. Kapłan kładzie obrączki początkowo na leżącą na solei $^{49}$ księgę Ewangelii, z której następnie podaje owe pierścienie ślubne obojgu narzeczonym. To widoczny znak tego, iż Sam Chrystus wręcza symbole miłości i tym samym błogosławi związek-sakrament małżeński, Przezeń ustanowiony ${ }^{50}$, a potrójne czyniony obrączkami znak krzyża nad głowami obojga narzeczonych, to zgodnie z pouczeniem, przywoływanego już świętego Tessalonickiego kaznodziei Symeona, cześć oddawana Trójcy Najświętszej ${ }^{51}$. To także jarki wzór do naśladowania boskiej jedności, jednomyślności i doskonałej miłości zachodzący między trzema Osobami Trójjedynego Boga jaki stawiany jest także nowożeńcom.

Jedna $\mathrm{z}$ modlitw zawartych $\mathrm{w}$ dawnych rękopisach, niebędąca już w użyciu liturgicznym Kościoła, podkreśla w znaczący sposób wymiar eschatologiczny błogosławieństwa i wręczenia ślubnych obrączek młodej parze. Owa czynność nazywana jest przez niektórych dziwnym terminem: „zaręczyny Chrztu”, które mają na celu przygotowanie do królewskiego ślubu i stanowią przedsmak życia wiecznego, wesela z Oblubieńcem Kościoła - Chrystusem ${ }^{52}$.

cieli lub tylko datę ślubu a niekiedy również wyrabiano i na jej wierzchu postać węża mającego symbolizować wieczność. M. Korolko, Leksykon kultury religijnej w Polsce, wyd. ADAM, Warszawa 1999, s. 372.

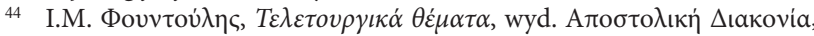
Aөriva 2002, s. 232.

45 С.В. Булгаков, Настольная книга для священнослужителей, Москва 1913, s. 1241.

46 Архиеп. Вениамин (Румовский), Новая Скрижаль: Объяснение о церкви, о литургии, и о всех службах и утварях, шуd. Православное Братство Святителя Филарета Митрополита Московского, Москва 1999, s. 226.

47 С.В. Булгаков, Настольная книга..., dz. cyt., s. 1241.

48 Архиеп. Вениамин (Румовский), Новая Скрижаль..., dz. cyt., s. 226.

${ }^{49} \mathrm{~W}$ tradycji greckiej nabożeństwo ślubu odbywa się przed samymi Kró-

lewskimi Drzwiami (cs. Царские Bpama), a nie na środku świątyni.

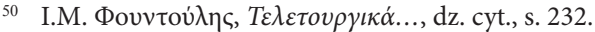

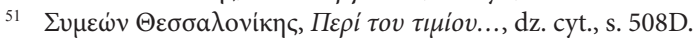

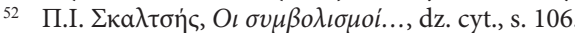




\section{Zakończenie}

Obrączka ślubna jest oznaką, dowodem i rękojmią zaślubin dwojga narzeczonych. Jej kolista forma, nieposiadająca ani początku, ani końca, która jest symbolem wieczności $^{53}$. Materia, z której się ją wykonuje ma stale przypominać małżonkom o tym, iż to nie oni sami, ale Ten, Który jest Alfą i Omega, Pierwszym i Ostatnim, Początkiem i Koncem ${ }^{54}$ włożył ją na ich ręce a miłość, jaka ich połączyła będzie niejednokrotnie wystawiana na próbę, lecz tak jak prawdziwe złoto doświadczane w ogniu nie ulegnie jakiemukolwiek uszkodzeniu, tak i ich miłość w chwilach trudnych odpie-

53 D. Forster, Świat symboliki... dz. cyt., s. 424.

54 (Ap 22, 13). rać będzie strzały pokus jakie kierować w nich będzie wróg rodzaju ludzkiego.

Poniższe słowa słynnego poematu A. Mickiewicza pt. „Pan Tadeusz” niech posłużą za epilog do powyższych rozważań:

\section{(...) bo serce młode i podróżne,}

Wiesz dobrze, jako miewa tentacyje różne; A wszakże, kiedy okiem rzuci na pierścionek I przypomni młodzieniec, że już jest małżonek, Zaraz w nim obcych pokus ostyga goraczka. Wierzaj mi, wielką sitę ma ślubna obraczka ${ }^{55}$.

55 A. Mickiewicz, Pan Tadeusz, czyli Ostatni zajazd na Litwie. Historia szlachecka zr. 1811 i 1812 we dwunastu księgach wierszem, wyd. Prószyński i S-ka, Warszawa 1996, s. 303.

\section{Bibliografia}

\section{Źródla}

Pismo Święte i dzieła Ojców oraz nauczycieli Kościoła

Biblia Tysiąclecia. Pismo święte Starego i Nowego Testamentu, wyd. Pallotinum, Poznań 2000.

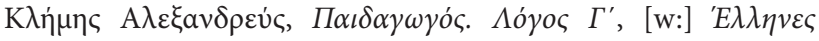

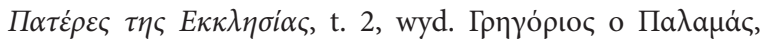

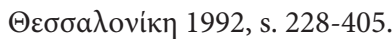

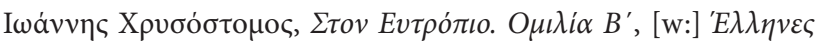

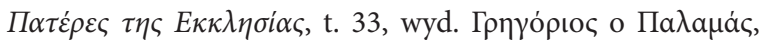

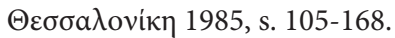

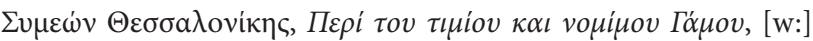
J.- P. Migne, Patrologiae Cursus Completus, Series Graeca, t. 155, Paris 1857-1866, s. 504-516.

\section{Literatura przedmiotu}

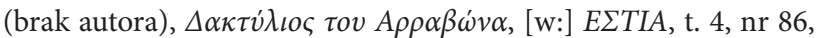

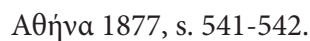

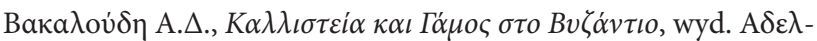

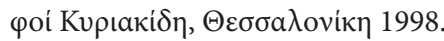

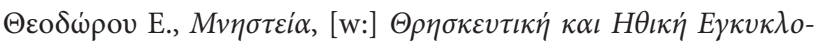

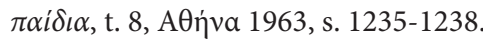

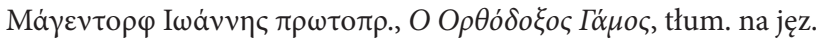

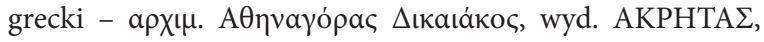
Néa $\Sigma \mu u ́ \rho v \eta 2004$.

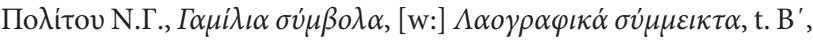
A日ńva 1921, s. 218-267.

$\Sigma \kappa \alpha \lambda \tau \sigma \eta \dot{~ П . I ., ~ O \iota ~ \sigma v \mu \beta о \lambda ı \sigma \mu о i ~ \sigma \tau \eta v ~ \alpha \kappa o \lambda o v \theta i \alpha ~ \tau o v ~ Г \alpha ́ \mu о v, ~[w:] ~}$

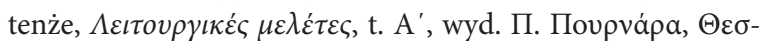

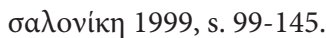

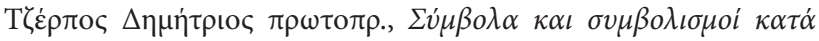

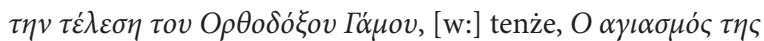

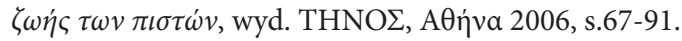

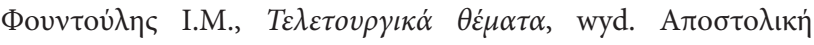

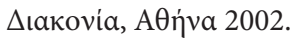

Желтов М.С2., Брак, [w:] Православная Енциклопедия, t. 6, wyd. Церковно-научный ценр Православная Енциклопедия, Москва 2003, s. 146-181.

\section{Literatura pomocnicza}

Forster D., Świat symboliki chrześcijańskiej. Leksykon, tłum. zbiorowe, wyd. PAX, Warszawa 2001.

Korolko M., Leksykon kultury religijnej w Polsce, wyd. ADAM, Warszawa 1999.

Lurker M., Słownik obrazów i symboli biblijnych, wyd. Pallottinum, Poznań 1989.

Ławreszuk M., Sakrament małżeństwa. Liturgiczna symbolika i znaczenie sakramentu w Kościele prawosławnym, Białystok 2014.

Mickiewicz A., Pan Tadeusz, czyli Ostatni zajazd na Litwie. Historia szlachecka $z$ r. 1811 i 1812 we dwunastu księgach wierszem, wyd. Prószyński i S-ka, Warszawa 1996.

Słownik grecko-polski, oprac. O. Jurewicz, t. 1, Wydawnictwo Szkolne PWN, Warszawa 2000.

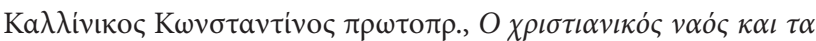

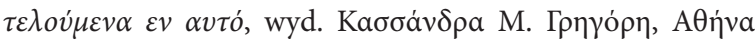
1969.

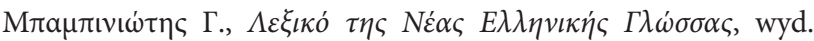

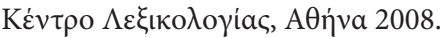

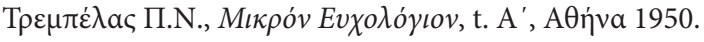

Булгаков С.В., Настольная книга для священнослужителей, Москва 1913.

(Румовский) Вениамин архиеп., Новая Скрижаль: Объяснение о церкви, о литургии, и о всех службах и утварях, wуd. Православное Братство Святителя Филарета Митрополита Московского, Москва 1999.

Шиманский Г.И., Литургика: Тачнства и обряды, wуd. Сретенский Монастыр, Москва 2003.

\section{Strony internetowe}

http://liturgia.cerkiew.pl/euch/malzenstwo/zareczyny.pdf [dostęp 17.06.2013]. 
http://liturgia.cerkiew.pl/euch/malzenstwo/zareczyny.pdf [dostęp 17.06.2013].

http://www.ourweddingday.gr/index.php/mnuweddinguide/ wedding/jewelrynaccessories/42-2011-05-02-16-49-32 [dostęp 20.09.2014]. http://liturgia.cerkiew.pl/euch/malzenstwo/zareczyny.pdf [dostęp 17.06.2013].

http://www.ourweddingday.gr/index.php/mnuweddinguide/ wedding/jewelrynaccesso es/41-2011-05-02-16-49-31 [dostęp 20.09.2013].

Rozmiar artykułu: 0,6 arkusza wydawniczego 